\title{
APPLICATION OF MAGNETIC RESONANCE SPECTROSCOPY IN THE DIFFERENTIATION OF HIGH-GRADE BRAIN NEOPLASM AND INFLAMMATORY BRAIN LESIONS
}

\author{
José Roberto Lopes Ferraz-Filho', Pedro Vieira Santana-Netto', \\ Jose Alves Rocha-Filho ${ }^{3}$, Aline Sgnolf ${ }^{2}$, Fernando Mauad ${ }^{3}$, Rafael Angelo Sanches ${ }^{4}$
}

\begin{abstract}
This study aims at evaluating the application of magnetic resonance spectroscopy (MRS) in the differential diagnosis of brain tumors and inflammatory brain lesions. The examinations of 81 individuals, who performed brain MRS and were retrospectively analyzed. The patients with ages between 10 and 80 years old, were divided into two groups. Group A consisted of 42 individuals with diagnoses of cerebral toxoplasmosis and Group B was formed of 39 individuals with diagnosis of glial neoplasms. On analyzing the ROC curve, the discriminatory boundary for the $\mathrm{Cho} / \mathrm{Cr}$ ratio between inflammatory lesions and tumors was 1.97 and for the $\mathrm{NAA} / \mathrm{Cr}$ ratio it was 1.12. RMS is an important method useful in the distinction of inflammatory brain lesions and high-degree tumors when the $\mathrm{Cho} / \mathrm{Cr}$ ratio is greater than 1.97 and the NAA/Cr ratio is less than 1.12. And so this method is important in the planning of treatment and monitoring of the therapeutic efficiency.
\end{abstract}

KEY WORDS: magnetic resonance image, spectroscopy, brain, neoplasm, inflammatory lesion.

\begin{abstract}
Aplicação da espectroscopia por ressonância magnética na diferenciação de lesões expansivas encefálicas neoplásicas e inflamatórias

Resumo - O presente estudo tem como objetivo avaliar a aplicação da espectroscopia por ressonância magnética (ERM) no diagnóstico diferencial entre lesões expansivas encefálicas inflamatórias e neoplásicas. Foram analisados retrospectivamente 81 indivíduos que realizaram exames de ERM com idade entre 10 a 18 anos, divididos em dois grupos. $\mathrm{O}$ grupo $\mathrm{A}$ foi formado por 42 indivíduos com diagnóstico de neurotoxoplasmose e o grupo B foi formado por 39 indivíduos com diagnóstico de neoplasias gliais. Após análise da curva ROC observou-se que o valor discriminatório da relação $\mathrm{Co} / \mathrm{Cr}$ entre lesões inflamatórias e neoplásicas foi de 1,97 e da relação $\mathrm{Naa} / \mathrm{Cr}$ foi de 1,12. A espectroscopia por RM é um método útil na distinção de lesões expansivas inflamatórias e neoplasias de alto grau quando a relação $\mathrm{Co} / \mathrm{Cr}$ é maior que 1,97 e a relação $\mathrm{Naa} / \mathrm{Cr}$ é menor que 1,12, o que torna este método importante no planejamento do tratamento e monitorização da eficácia terapêutica.
\end{abstract}

PALAVRAS-CHAVE: ressonância magnética, espectroscopia, encéfalo, neoplasia, lesão inflamatória.

Magnetic resonance spectroscopy (MRS) is a relatively fast, non-invasive method that provides metabolic/ biochemical information of the normal brain parenchyma and of pathological processes ${ }^{1,2}$. Spectroscopy utilizes the same physical principles as conventional magnetic resonance, but differs in the way that the data are pro- cessed and presented;instead of images, amplitude by frequency plots are obtained'.

There are few published studies concerning the differentiation between inflammatory lesions and brain tumors employing MRS and all that exist are related to the differential diagnosis of lymphoma and inflammatory lesions in

FAMERP Medical School, São José do Rio Preto SP, Brazil: 'MD, Radiologist of the Image Department, Doctor's candidate Health Sciences Program, FAMERP Medical School; ${ }^{2}$ MD, Fellow at the Image Department, FAMERP Medical School; ${ }^{3}$ MD, Fellow at the radiology Department and Doctor's Candidate; ${ }^{4} \mathrm{MD}$, Radiologist of the Imaging Department, FAMERP Medical School.

Received 25 August 2008, received in final form 13 November 2008. Accepted 6 February 2009.

Dr. José Roberto Lopes Ferraz-Filho - Image Department / FAMERP - Avenida Brigadeiro Faria Lima 5544 - 15090 -000 São José do Rio Preto SP - Brasil. E-mail:jrl.ferraz@terra.com.br 
patients with human immunodeficiency virus (HIV) infections $^{3-6}$. HIV may initially manifest with neurological symptoms which at times mimic tumors ${ }^{7,8}$.

This study aims at evaluating the application of MRS in the differential diagnosis of brain tumors and inflammatory brain lesions.

\section{METHOD}

The examinations of 81 individuals, who performed brain MRS from 2004 to 2007, were retrospectively analyzed. The patients, of both genders, with ages between 10 and 80 years old, were divided into two groups. Group A consisted of 42 individuals with diagnoses of cerebral toxoplasmosis with single or multiple lesions confirmed by cerebrospinal fluid (CSF) and clinicoradiological responses to anti-toxoplasmosis therapy. Group B was formed of 39 individuals with diagnosis of glial neoplasms (Grade III and IV gliomas according to the World Health Organization classification) confirmed by means of anatomopathological studies.

The inclusion criteria utilized in this study were that patients were older than 10 years old, the MRS was of a good technical standard, the voxel included the highest possible volume of pathological tissue and the etiological diagnosis of the lesions were definitive.

The MRI examinations were performed in the Magnetic Resonance Service using a Philips Medical Systems Gyroscan Intera (Best, Netherlands) 1.5 Tesla scanner.

The protocol included turbo spin-echo axial T2-weighted sequences (TE 110, TR 4466, 5mm slice thickness and 1-mm gap);spin-echo sagital T1-weighted (TE 15, TR 550, 5-mm slice thickness and 1-mm gap);axial fluid-attenuated inversion recovery - FLAIR (TE 120, TR 6000, 5-mm slice thickness and 1-mm gap);axial diffusion weighted (TE 86, TR 1000, 5-mm slice thickness and 1-mm gap) and spin-echo axial, sagital and coronal T1weighted imaging after intravenous administration of paramagnetic contrast at $0.1 \mathrm{mmol} / \mathrm{kg}$ (TE 15, TR 550, 5-mm slice thickness and 1-mm gap).

The RMS was achieved during conventional MR image acquisition. The single-voxel technique was employed using a standard voxel volume of $8.0 \mathrm{~cm}^{3}(2.0 \times 2.0 \times 2.0 \mathrm{~cm})$ or at least 3.37 $\mathrm{cm}^{3}(1.5 \times 1.5 \times 1.5 \mathrm{~cm})$ applied in smaller lesions. The parameters utilized for acquisition were the PRESS technique using a TE of $144 \mathrm{~m} / \mathrm{s}$. Shimming was automatically performed, followed by chemically selected saturation (CHESS) for water suppression. Metabolites were always shown, on the $\mathrm{x}$ axis in parts per million (ppm) and on the $y$ axis, by the height of the metabolite peaks in an expressed scale at an arbitrary intensity.

The metabolites studied were choline (Cho) which appears at $3.22 \mathrm{ppm}$, creatine $(\mathrm{Cr})$ at 3.02, $\mathrm{N}$-acetyl aspartate (NAA) at $2.01 \mathrm{ppm}$, Lipid at 0.8 to $1.3 \mathrm{ppm}$ and lactate at 1.32 to $1.33 \mathrm{ppm}$. The Cho/Cr and NAA/Cr ratios were analyzed as was the presence of lipids and lactate.

The sensitivity and specificity of MRS in the distinction of inflammatory lesions and brain tumors by means of the $\mathrm{Cho} / \mathrm{Cr}$ and NAA/Cr ratios were estimated by analyzing the ROC curve and by multiple logistic regression. The results are presented as percentages with $95 \%$ confidence intervals. An alpha error of $5 \%$ was considered acceptable. This work was approved by the institution's Research Ethics Committee.

\section{RESULTS}

Of the 81 patients included in the study, Group A with diagnosis of toxoplasmosis, had a mean age of 41 years old and Group B, with diagnosis of glial neoplasms had a mean age of 51 years old. Seven patients had grade III and 32 had grade IV glial neoplasms.

On analyzing the ROC curve, the discriminatory boundary for the Cho/Cr ratio between inflammatory lesions and tumors was 1.97. The sensitivity of the $\mathrm{Cho} / \mathrm{Cr}$ ratio to detect neoplasms was $77 \%(95 \% \mathrm{Cl}: 61-89)$ with a $p$-value $=0.001$ and the specificity was $79 \%(95 \% \mathrm{Cl}: 63-$ 90) with a $p$-value $=0.001$. The sensitivity of the NAA/Cr ratio to detect neoplasms was $64 \%$ (95\% Cl: $47-78)$ with a p-value $=0.108$ and the specificity was $69 \%(95 \% \mathrm{Cl}$ : $52-$ 82) with a $p$-value $=0.020$.

On analyzing together, the specificity of the method increased to $97.6 \%$ with a $\mathrm{p}$-value $=0.001$ when the Cho/ $\mathrm{Cr}$ ratio was greater than 1.97 and the NAA/Cr ratio was less than 1.12 at detect neoplasm (Fig 1).

Multiple logical regression analysis, established with a reference value of 1.97, was significant for the $\mathrm{Cho} / \mathrm{Cr}$ ratio ( $p$-value $=0.001$ and Odds Ratio=11.9), the NAA $/ \mathrm{Cr}$ ratio ( $p$-value $=0.03$ and Odds Ratio $=3.6)$ and for age $(p-$ value $=0.02$ and Odds Ratio=1.04).

No discriminatory power was observed for the presence of lipid and lactate metabolites.

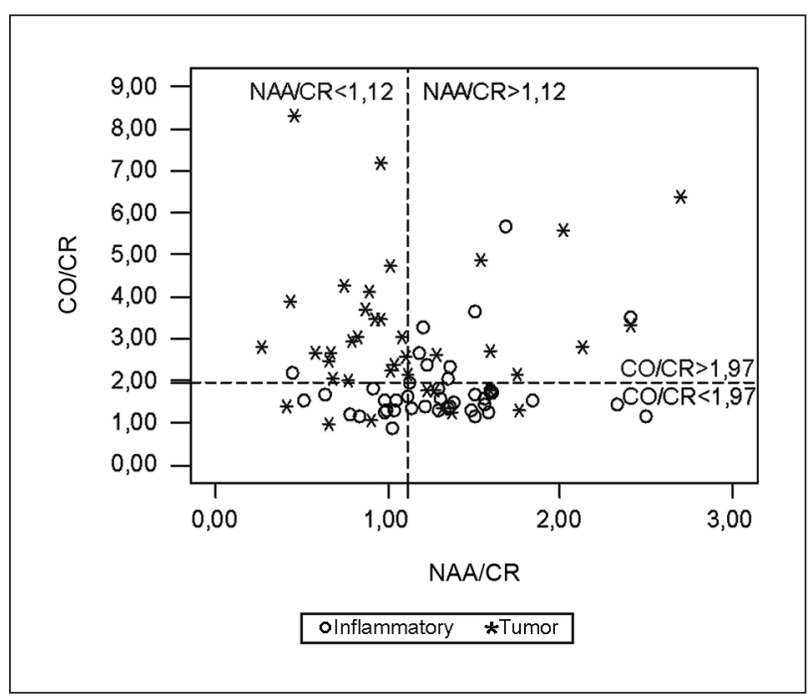

Fig 1. Graphic representation of $\mathrm{Cho} / \mathrm{Cr}$ ratio and $\mathrm{NAA} / \mathrm{Cr}$ ratio at diagnoses of the neoplasm and inflammatory brain lesions. 

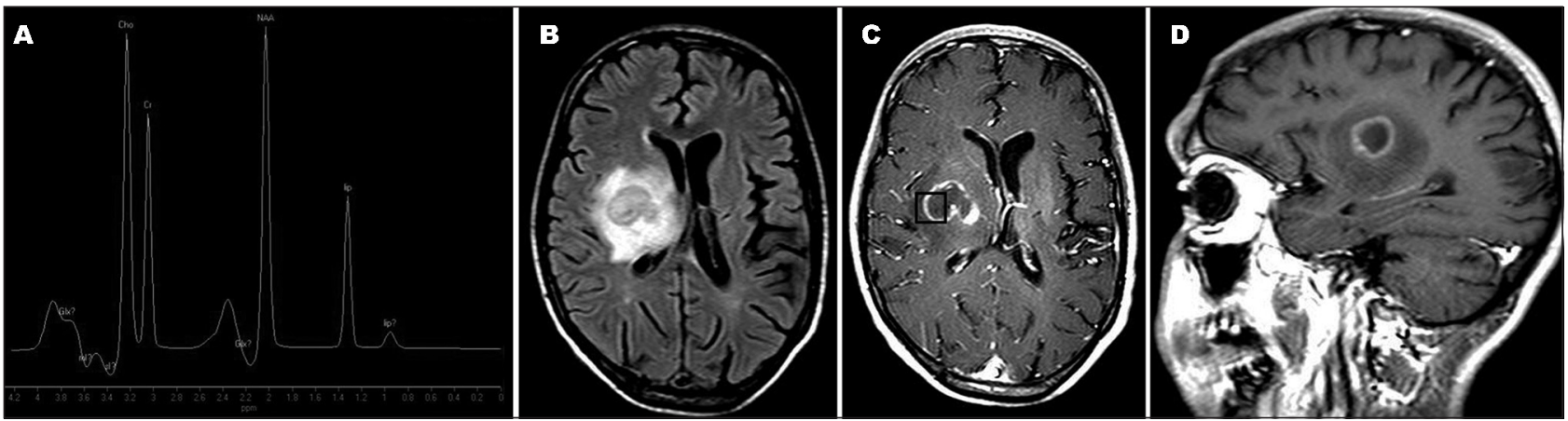

Fig 2. Toxoplasma encephalitis. [A] MR spectroscopy showing increases of Cho (Cho/Cr ratio=1.33), reductions of NAA (NAA/Cr ratio=1.35) and the lipid peak. [B, C, D] FLAIR sequence and T1-weighted after contrast showing nodular lesion with ring-enhancement and necrotic centrally located in the basal ganglia to the right.
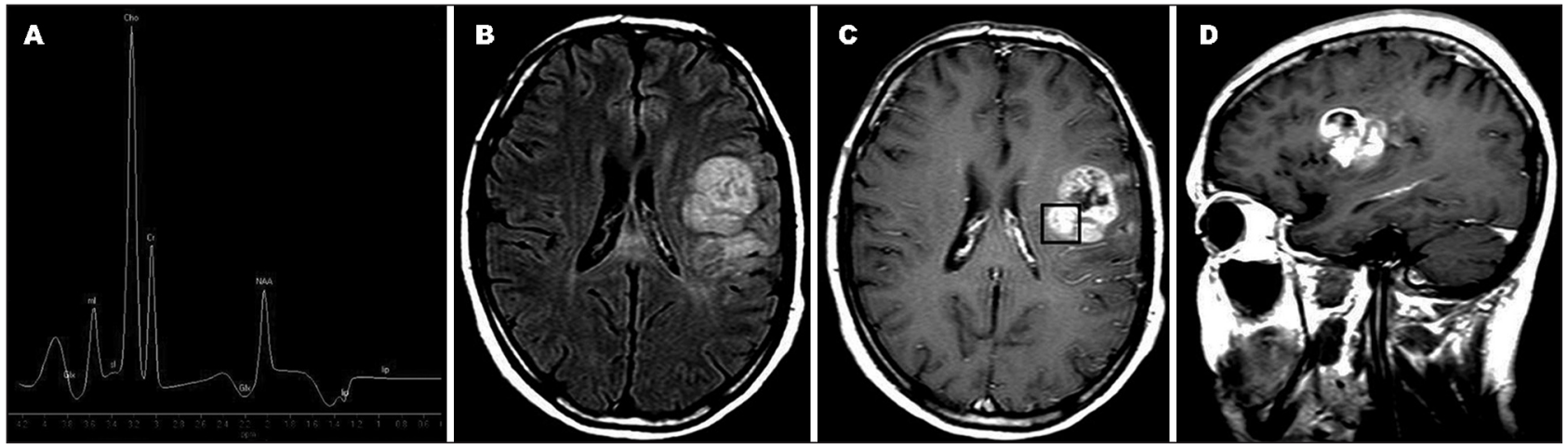

Fig 3. Glioblastoma multiforme. [A] MR spectroscopy showing increases of Cho (Cho/Cr ratio=2.41), reductions of NAA (NAA/Cr ratio=0.58). $[B, C, D]$ FLAIR sequence and T7-weighted after contrast showing nodular lesion with irregular enhancement and necrotic centrally located in the left frontal lobe.

\section{DISCUSSION}

The present study showed that MRS can discriminate between high-degree glial tumors and cerebral toxoplasmosis when the $\mathrm{Cho} / \mathrm{Cr}$ ratio is greater than 1.97 (Figs 2 and 3). The use of the $\mathrm{Cho} / \mathrm{Cr}$ ratio in the evaluation of neoplastic lesions has already been described in the literature as Cho is an important constitute of cell membranes with increases occurring when there are increases in cell synthesis and conversion to carcinogenic cells, while creatine is generally stable ${ }^{8,9}$. NAA is found in normal neurons and when altered, reductions occur both in tumors and in inflammatory lesions thereby indicating neuronal loss. The NAA/Cr ratio has discriminatory value when analyzed together with the $\mathrm{Cho} / \mathrm{Cr}$ ratio increasing the specificity of the method ${ }^{10}$.

As of yet we have no knowledge of MRS investigations comparing high-degree glial tumors and cerebral toxoplasmosis and thus there are few published data to compare with the results of this study. Existing publications are conflicting and compare cerebral toxoplasmosis with lymphomas, which is the most common brain tumor in patients with HIV. Chinn et al. ${ }^{4}$ studied 18 patients with cerebral toxoplasmosis and 9 with lymphomas and con- cluded that the $\mathrm{Cho} / \mathrm{Cr}$ and NAA/Cr ratios are not useful in the differentiation of the two diseases; this conclusion was also supported by Simone et al. ${ }^{5}$ Chang et al. ${ }^{3}$, who studied 11 patients with cerebral toxoplasmosis and 8 with lymphomas, did not utilize ratios between metabolites in their studies but ascertained that MRS is useful for differentiation, thus agreeing with the conclusion of Harting et al."

In MRS studies evaluating gliomas, Meng Law et al. ${ }^{12}$ reported that this method is useful in the differentiation of high- and low-degree glial tumors with the Cho/Cr ratio being higher than 1.56 in high-degree tumors. These data are sustained in studies by Fayed et al..$^{13}$ who demonstrated that a Cho/Cr ratio greater than 1.55 has a discriminatory power to differentiate between high- and low-grade glial tumors ${ }^{13-15}$.

Another previously described situation is the association of glial tumors in HIV seropositive individuals ${ }^{16-19}$. This association has become more common due to recently developed drugs and the efficacy of treatment, thereby increasing survival of HIV seropositive patients. However, of the 39 patients diagnosed with glial tumors in this study, only 10 had been tested for HIV with none of them 
being seropositive. Additionally, none of the HIV seropositive patients presented with glial tumors.

The differentiation between inflammatory lesions and tumors may help in the early establishment of therapy which is essential for better prognoses with cerebral toxoplasmosis lesions and may also avoid inappropriate treatment of tumor patients that may cause allergic reactions or hematogenic intoxication with impairment of the general state of already debilitated patients ${ }^{20,21}$.

Hence, the reason for this study was, that on some occasions, the first manifestations of HIV infection are neurological alterations caused by cerebral toxoplasmosis. When the results of other examinations are unknown, differentiation diagnosis based only on conventional magnetic resonance may not be possible and so MRS plays an important role r, $^{7,8}$.

In conclusion, RMS is an important method useful in the distinction of inflammatory brain lesions and highdegree tumors when the $\mathrm{Cho} / \mathrm{Cr}$ ratio is greater than 1.97 and the NAA/Cr ratio is less than 1.12. And so this method is important in the planning of treatment and monitoring of the therapeutic efficiency.

\section{REFERENCES}

1. Cousing JP. Clinical MR spectroscopy fundamentals, current applications and future potentials. AJR 1995;164:1337-1347.

2. Katz DS, Fatouros PP, Weissman JL, Eyler WR, Siegelman SS. Brain abscesses: etiologic categorization with in vivo proton MR spectroscopy. Radiology 2004;230:519-527.

3. Chang L, Miller BL, McBride D, et al. Brain lesions in patients with AIDS: H-1 MR spectroscopy. Radiology 1995;197:525-531.

4. Chinn RJ, Wilkinson ID, Hall-Craggs MA, et al. Toxoplasmosis and primary central nervous system lymphoma in HIV infection: diagnosis with MR spectroscopy. Radiology 1995;197:649-654.

5. Simone IL, Federico F, Tortorella C, et al. Localised 1H-MR spectroscopy for metabolic characterisation of diffuse and focal brain lesions in patients infected with HIV. J Neurol Neurosurg Psychiatry 1998;64:516-523.

6. Yamagata NT, Miller BL, McBride D, et al. In vivo proton spectroscopy of intracranial infections and neoplasms. J Neuroimaging 1994;4:23-28.

7. Cortsen ME, Skot J, Skriver EB. Cerebral toxoplasmosis primarily diagnosed as a tumor. Ugeskr Laeger 1992;154:645-646.

8. Roricht S, Meyer BU, Grafin von EH, Sander B. A solitary toxoplasmosis focus simulating a brain tumor as the first manifestation of AIDS. Rofo 1997;167:201-203.
9. Luyten PR, Marien AJ, Heindel W, et al. Metabolic imaging of patients with intracranial tumors: H-1 MR spectroscopic imaging and PET. Radiology 1990;176:791-799.

10. Al-Okaili RN, Krejza J, Wang S, Woo JH, Melhem ER. Advanced MR imaging techniques in the diagnosis of intraaxial brain tumors in adults. Radiographics 2006;26(Suppl 1):S173-S189.

11. Harting I, Hartmann M, Jost G, et al. Differentiating primary central nervous system lymphoma from glioma in humans using localised proton magnetic resonance spectroscopy. Neurosci Lett 2003;342:163-166.

12. Law M, Yang S, Wang H, et al. Glioma grading: sensitivity, specificity, and predictive values of perfusion MR imaging and proton MR spectroscopic imaging compare with conventional MR imaging. AJNR 2003;24:1989-1998.

13. Fayed N, Modrego PJ. The contribution of magnetic resonance spectroscopy and echoplanar perfusion-weighted MRI in the initial assessment of brain tumours. J Neurooncol 2005;72:261-265.

14. Fayed N, Dávila J, Medrano J, Olmos S. Malignancy assessment of brain tumours with magnetic resonance spectroscopy and dynamic susceptibility contrast MRI. Eur J Radiol. 2008; 427-433.

15. Fayed N, Morales H, Modrego PJ, Pina MA. Contrast/ Noise ratio on conventional MRI and choline/creatine ratio on proton MRI spectroscopy accurately discriminate low-grade from high-grade cerebral gliomas. Acad Radiol. 2006;13:728-737.

16. Blumenthal DT, Raizer JJ, Rosenblum MK, Bilsky MH, Hariharan S, Abrey LE. Primary intracranial neoplasms in patients with HIV. Neurology 1999;52:1648-1651.

17. Moulignier A, Mikol J, Thiebaut JB, Eliaszewicz M, Meyohas MC, Frottier J. Cerebral glioblastoma: a new complication of HIV-1 infection. Presse Med 1992;21:895-898.

18. Moulignier A, Mikol J, Pialoux G, Eliaszewicz M, Thurel C, Thiebaut JB. Cerebral glial tumors and human immunodeficiency virus-1 infection. More than a coincidental association. Cancer 1994;74:686-692.

19. Vannemreddy PS, Fowler M, Polin RS, Todd JR, Nanda A. Glioblastoma multiforme in a case of acquired immunodeficiency syndrome: investigation a possible oncogenic influence of human immunodeficiency virus on glial cells. Case report and review of the literature. J Neurosurg 2000;92:161-164.

20. Ernst TM, Chang L, Witt MD, et al. Cerebral toxoplasmosis and lymphoma in AIDS: perfusion MR imaging experience in 13 patients. Radiology 1998;208:663-669.

21. Batra A, Tripathi RP, Gorthi SP. Magnetic resonance evaluation of cerebral toxoplasmosis in patients with the acquired immunodeficiency syndrome. Acta Radiol 2004;45:212-221. 